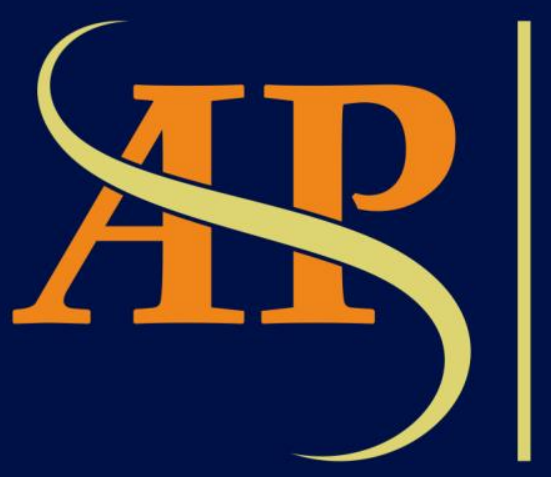

JURNAL

ASIA

PACIFIC

STUDIES

Journal of International Relations Study Program Faculty of Social and Political Sciences

Universitas Kristen Indonesia

Volume I | Number 1 | January- June 2017 


\title{
JEJARING ILLEGAL FISHING DI PERBATASAN INDONESIA-FILIPINA
}

\author{
Yosua Jaya Edy ${ }^{1}$, Sunyoto Usman ${ }^{2}$, Moh. Najib Azca ${ }^{3}$ \\ ${ }^{1}$ Pusat Pengembangan ASN, Badan Kepegawaian Negara, Bogor, 16720 \\ ${ }^{2}$ Dept. Sosiologi, Fakultas Ilmu Sosial dan Ilmu Politik, Universitas Gadjah Mada, Yogyakarta, 55281 \\ ${ }^{3}$ Dept. Sosiologi, Fakultas Ilmu Sosial dan Ilmu Politik, Universitas Gadjah Mada, Yogyakarta, 55281 \\ 11yosuaedy@gmail.com \\ 2sunyotousman@yahoo.com \\ ${ }^{3}$ najibazca@gmail.com
}

\begin{abstract}
Illegal fishing, known as IUU (illegal, unreported, unregulated) fisheries has long been happening throughout the territorial waters of the Republic of Indonesia. Talaud waters as border regions of Indonesia-Philippines also have the same problem. This study uses a network analysis approach with intensive field research for three years from 2014 to 2016, this research aims to determine the range of networks developed by actors involved in illegal fishing.

The research found that illegal fishing activities in the area occurred at three levels, namely illegal fishing in communal networks, illegal fishing in associational networks and illegal fishing in industrial networks. The pattern of illegal fishing that occurs in communal networks is done by small fishermen (peasant fisher) with the characteristics of the use of traditional fishing gear, small scale, limited area and relatively subsistence. In an associational network the pattern of illegal fishing takes place on a wider scale, carried out by a post-peasant fisher with a more modern fishing gear, and involving local apparatus and officials. Meanwhile, illegal fishing in industrial networks is conducted by corporations involving high-ranking officials of policy-making countries at the central level, as well as by industry-scale entrepreneurs and fishermen.

The strength of the illegal fishing network in the Indonesia-Philippines border region cannot be separated from the role of brokers or intermediaries that exist in every network. Brokers have an important role to connect actors involved in illegal fishing. One of the interesting findings of this research is that the role of brokers can also be carried out by state apparatus or parties related to the state apparatus.
\end{abstract}

Keywords: illegal fishing, social network, broker, border area.

\begin{abstract}
Abstrak
Illegal fishing atau yang dikenal dengan praktik perikanan IUU (illegal, unreported, unregulated) sudah lama terjadi di seluruh wilayah perairan Republik Indonesia. Perairan Talaud sebagai wilayah perbatasan IndonesiaFilipina juga memiliki persoalan yang sama. Penelitian ini menggunakan pendekatan analisis jaringan dengan riset lapangan secara intensif selama tiga tahun sejak 2014 hingga 2016, riset ini bertujuan untuk mengetahui ragam jejaring yang dikembangkan oleh aktor yang terlibat dalam illegal fishing.

Riset ini menemukan, kegiatan illegal fishing yang terjadi di wilayah tersebut terjadi pada tiga level yaitu illegal fishing dalam jejaring komunal, illegal fishing dalam jejaring asosiasional dan illegal fishing dalam jejaring industrial. Pola illegal fishing yang terjadi dalam jejaring komunal dilakukan oleh nelayan kecil (peasant fisher) dengan ciri penggunaan alat tangkap tradisional, berskala kecil, area terbatas dan relatif bersifat subsisten. Dalam jejaring asosiasional pola illegal fishing terjadi dalam skala yang lebih luas, dilakukan oleh nelayan skala menengah (post-peasant fisher) dengan alat tangkap yang lebih modern, serta melibatkan aparat dan pejabat lokal. Sedangkan illegal fishing dalam jejaring industrial dilakukan oleh korporasi dengan melibatkan oknum pejabat tinggi negara pembuat kebijakan di tingkat pusat, serta dilakukan oleh pengusaha dan nelayan skala industri.

Kuatnya jejaring illegal fishing di wilayah perbatasan Indonesia-Filipina ini tidak dapat dilepaskan dari peranan broker atau perantara yang ada di dalam setiap ragam jejaring. Broker memiliki peran penting menyambungkan aktor-aktor yang terlibat dalam illegal fishing. Salah satu temuan menarik riset ini adalah peranan broker dapat juga dilakukan oleh aparat negara atau pihak yang terkait dengan aparat negara.
\end{abstract}

Kata kunci: illegal fishing, jaringan sosial, broker, wilayah perbatasan. 


\section{Pendahuluan}

\subsection{Latar Belakang}

Secara geografis Indonesia memiliki garis pantai yang sangat panjang sekitar 99.093 $\mathrm{km}$, dengan luas laut teritorial $284.210,90 \mathrm{~km}^{2}$, Luas Zona Ekonomi Eksklusif 2.97 juta $\mathrm{km}^{2}$, Luas laut 12 Mil $279.322 \mathrm{~km}^{2}$, garis perbatasan darat sepanjang 3.032 kilometer, 92 pulaupulau kecil berada pada posisi terluar, 67 pulau diantaranya berbatasan langsung dengan negara tetangga. Perbatasan laut dengan 10 negara dan perbatasan darat dengan 3 negara (Kelautan dan Perikanan Dalam Angka 2015, 139). Dengan letak geografis yang strategis dikelilingi laut maka Indonesia memiliki potensi sumber daya perikanan yang sangat besar. Keputusan Menteri Kelautan dan Perikanan Nomor RI No. Kep. 45/MEN/2011 tentang Estimasi Potensi Sumberdaya Ikan di Wilayah Pengelolaan Perikanan Negara RI mencatat potensi perikanan laut diperairan Indonesia mencapai 6,5 juta ton/tahun namun potensi yang ada belum dapat dimanfaatkan secara optimal dan berkesinambungan, permasalahan yang muncul justru maraknya penangkapan ikan secara ilegal yang lazim dikenal sebagai illegal fishing.

Sebagai negara kepulauan yang sangat kaya ikan, penangkapan ikan secara ilegal marak dan menjadi tantangan tersendiri yang dihadapi Indonesia. Kemampuan pengawasan laut yang sangat terbatas dan luasnya perairan yang dihadapi, membuat kegiatan illegal fishing atau yang dikenal dengan istilah Illegal Unreported and Unregulated Fishing (IUU Fishing) masih menjadi masalah besar bagi Indonesia. Fenomena illegal fishing tersebut juga marak dijumpai di perairan Kabupaten Kepulauan Talaud, daerah perbatasan antara Indonesia dan Filipina. Perairan Talaud merupakan bagian dari Laut Sulawesi (Celebes Sea) yang tercatat memiliki keanekaragaman hayati bawah laut terbaik di Asia Pasifik, dan sumber daya ikan yang melimpah. Tidak mengeherankan jika di perairan Talaud ini tercatat sebagai daerah yang memiliki tingkat illegal fishing sangat tinggi dibanding daerah lain di wilayah Republik Indonesia. Pelanggaran tersebut terutama dilakukan oleh kapal ikan asing (KIA) berbendera Filipina, Vietnam dan Malaysia (Palma \& Tsamenyi 2008, 3).

Maraknya illegal fishing di perbatasan Indonesia-Filipina ini tidak lepas dari faktor luasnya cakupan wilayah dan kondisi geografis yang sulit dijangkau, menjadikan sulitnya pengamanan oleh aparat ditambah faktor sarana dan prasarana yang terbatas. Fenomena illegal fishing di wilayah perbatasan terus terjadi dengan intensitas yang lebih besar dan beragam, tidak saja kapal berbendera asing yang melakukan penangkapan ikan secara ilegal bahkan kapal berbendera Indonesia juga kerap melakukan hal serupa. Nelayan Filipina dapat dengan leluasa masuk ke perairan Sulawesi Utara, khususnya wilayah perairan Talaud karena gugusan Kepulauan Talaud yang benar-benar terletak di tengah laut lepas. Hanya dibutuhkan 4 jam perjalanan menuju Pulau Mindanao, pulau paling selatan dari wilayah Filipina. Luasnya wilayah serta minimnya sarana pengawas membuat nelayan Filipina dapat dengan leluasa mencuri ikan di wilayah perairan Talaud.

Meskipun berbagai cara telah diupayakan oleh pemerintah didalam menyikapi fenomena illegal fishing, namun ditengarai praktek illegal fishing tersebut tetap berlangsung, bahkan dengan instensitas yang kian masif. Penelitian ini berfokus pada jejaring sosial illegal fishing di kawasan perbatasan Indonesia - Filipina. Kajian meliputi aktor, dinamika, lokasi, dan pola jaringan sosial yang berhubungan dengan kegiatan illegalfishing. Illegal fishing di wilayah perbatasan Indonesia - Filipina 
sangat kompleks, setiap aktor yang terlibat memiliki latar belakang motivasi yang berbeda didalam melakukan kegiatan penangkapan ikan ilegal. Variasi alat tangkap, area penangkapan ikan serta jalur distribusi hasil penangkapan ikan secara ilegal mewarnai dinamika kegiatan illegal fishing di wilayah perbatasan Indonesia - Filipina. Nelayan lokal dihadapkan pada kondisi serba sulit karena harus hidup dengan berbagai kekurangan di wilayah perbatasan dan disisi lain harus bersaing dengan para pencuri ikan dari negara lain dengan alat tangkap yang jauh lebih besar. Konstruksi sosial setiap aktor di dalam memaknai konsep illegal fishing menjadikan fenomena pencurian ikan di wilayah perbatasan selalu berkembang dengan berbagai dinamikanya.

Beberapa hasil kajian penelitian yang substansi dan locus nya relevan serta dapat digunakan sebagai bahan literatur pendukung antara lain penelitian yang menyimpulkan bahwa fenomena illegal fishing yang terjadi khususnya di wilayah Samudera Pasifik merupakan sebuah bentuk kejahatan lintas negara yang terorganisasi dengan baik. Penelitian ini berusaha memberikan konseptualisasi illegal fishing sebagai bagian dari jaringan kejahatan yang terorganisir sehingga dengan demikian lebih mudah untuk mengidentifikasi prioritas politik yang ditempuh oleh sebuah Negara di dalam menyikapi fenomena illegal fishing (Osterblom, Constable, \& Fukumi 2011, 10).

Fenomena illegal fishing sejatinya merupakan sebuah usaha bisnis yang dilakukan oleh jaringan kejahatan lintas negara yang terjadi karena "fasilitas" lemahnya penegakan hukum maupun adanya celah dari peraturan yang mengatur tentang eksploitasi hasil sumber daya kelautan. Secara umum penelitian ini menyimpulkan bahwa fenomena illegal fishing dalam skala besar masif terjadi hampir diseluruh wilayah perairan dikarenakan lemahnya negara dalam proses pengawasan dan penegakan hukum, dan diperparah dengan keterlibatan aparatur dalam jaringan internasional pencurian ikan (Telesetsky 2015, 939-996).

Maraknya illegal fishing di Laut Sulawesi tidak dapat dilepaskan oleh faktor kemiskinan dan kondisi sosial masyarakat nelayan. Ketiadaaan alternatif pekerjaan, rendahnya tingkat pendidikan dan tingkat ketergantungan terhadap nelayan besar (majikan kapal) menjadikan tidak ada pilihan lain bagi nelayan untuk mencari tangkapan ikan sebanyak mungkin dengan cara-cara illegal. Mudahnya memperoleh bahan-bahan peledak seperti amonium nitrat (NH4NO3) dan botol peledak, bahan kimia seperti sodium sianida ( $\mathrm{NaCN})$ serta lemahnya pengawasan pihak keamanan di wilayah perbatasan menjadikan fenomena illegal fishing di Laut Sulawesi kian marak.

Dalam lingkup yang lebih luas, praktik illegal fishing ternyata melibatkan aparat dan pejabat negara. Keterlibatan pejabat negara dan aparat keamanan dalam praktik kejahatan illegal fishing. Temuan penelitian ini cukup mengejutkan, pada tahun 2002 perusahaan perikanan yang berbasis di Afrika Selatan hampir seluruhnya melakukan praktik penyuapan terhadap inspektur atau pengawas perikanan. Pejabat perlu disogok untuk mendapatkan izin penangkapan ikan, atau tetap dibiarkan menangkap ikan meskipun tanpa adanya izin. Praktik suap kepada pejabat dan aparat keamanan pada prinsipnya adalah faktor yang siginifikan di dalam upaya penegakan hukum, sehingga praktik illegal fishing terus berlanjut di Afrika Selatan (Martini 2013, 4).

Banyak praktik ilegal di Laut Bering dalam industri perikanan yang melibatkan pejabat dan pengusaha perikanan. Dalam setiap rantai distribusi hasil perikanan tangkap, di dalamnya sarat akan praktik pencucian uang. Dana hasil kegiatan perikanan ilegal kemudian diinvestasikan ke dalam bentuk pembelian atau pembangunan infrastruktur seperti membeli perlengkapan baru, pembangunan pabrik pengolahan ikan baru maupun pembelian kapal baru. Kerja sama yang terjalin antara aparat, pejabat dan pengusaha perikanan ini semakin memperkuat bisnis perikanan ilegal (Putt and Anderson 2007, 23-24).

Praktik perikanan ilegal yang melibatkan unsur negara juga terjadi di kepulauan Solomon dan Guinea. Pada tahun 2008, pemerintah Guinea secara resmi mengumumkan bahwa 
negara mengalami kerugian sebesar $€ 1$ juta dikarenakan praktek illegal fishing yang dilakukan oleh Menteri Perikanan negara ini. Pada tahun 2005, pemerintah Solomon menyatakan bahwa negara kehilangan potensi pendapatan negara sebesar $\$ 9$ juta, sebagai akibat korupsi dan kecurangan dalam hal penerbitan perizinan penangkapan ikan. Studi Bondaroff ini juga menemukan adanya praktik suap sebesar $¥ 500$ juta yang dilakukan oleh perusahaan Jepang kepada pejabat perikanan di Rusia untuk meningkatkan kuota impor ikan (Bondaroff 2015, 50).

Indonesia sebagai negara kepulauan dan negara pantai sangat berkepentingan untuk turut serta menanggulangi masalah pencurian sumber daya ikan atau aktivitas penangkapan sumber daya ikan secara ilegal. Hampir semua negara telah meratifikasi baik konvensi hukum internasional maupun kesepakatan dan perjanjian internasional untuk menekan aktivitas penangkapan ikan secara ilegal. Indonesia termasuk negara yang telah meratifikasi beberapa konvensi, kesepakatan serta perjanjian bilateral maupun internasional dalam rezim perikanan global.

Berbagai upaya penanggulangan illegal fishing di Indonesia tampaknya belum membuahkan hasil yang optimal, berbagai media masih memberitakan maraknya illegal fishing di wilayah perbatasan Indonesia. Keterlibatan oknum pejabat negara dan oknum aparat keamanan dalam praktik illegal fishing merupakan salah satu faktor dominan masifnya kegiatan pencurian ikan. Oknum pejabat negara dan aparat keamanan selain terlibat langsung dalam praktik peyalahgunaan wewenang, dalam beberapa kasus juga aktif berperan sebagai broker/perantara yang menjembatani antara pengusaha perikanan dengan pemberi perizinan.

Dari beberapa penelitian terdahulu, studi kawasan perbatasan belum cukup membicarakan isu yang kompleks secara mendalam jika dikaitkan dengan fenomena illegal fishing. Studi tentang perbatasan masih dominan berkutat pada pemetaan berbagai permasalahan yang ada serta pemetaan potensi yang dimiliki oleh kawasan perbatasan, tanpa adanya tawaran kebijakan yang konkrit. Sementara itu, penelitian yang terkait dengan jaringan sosial juga tidak banyak yang mengkaji sektor ekonomi ilegal, kegiatan illegal fishing selama ini dominan didekati dalam perspektif hukum semata tanpa mencoba memahami mengapa illegal fishing kian marak dan massif. Penelitian ini diharapkan dapat menggambarkan bentuk jaringan sosial yang dikembangkan dan dipelihara para penduduk perbatasan dalam bentuk kegiatan illegal fishing, serta strategi pelaku dan broker di dalam praktik perikanan illegal.

\subsection{Rumusan Masalah}

Dari uraian latar belakang di atas maka beberapa permasalahan penting terkait dengan illegal fishing di perbatasan adalah bahwa kegiatan penangkapan ikan yang tidak sesuai dengan prosedur yang ditetapkan oleh negara/ pemerintah semakin marak dan terkesan tidak tersentuh oleh upaya aparat untuk meminimalisir kegiatan tersebut. Dengan demikian diperlukan upaya untuk mencari penjelasan mengapa hal tersebut marak terjadi dan bagaimana proses rentetan terjadinya kegiatan illegal fishing yang terjadi di kawasan perbatasan Indonesia-Filipina, khususnya di wilayah Kabupaten Kepulauan Talaud. Kegiatan illegal fishing terjadi dengan intensitas yang besar dan beragam, aktor yang terlibat memiliki jaringan yang terorganisir dengan baik.

Illegal fishing di wilayah perbatasan Indonesia-Filipina sangat kompleks, setiap aktor yang terlibat memiliki latar belakang motivasi yang berbeda didalam melakukan kegiatan penangkapan ikan ilegal. Variasi alat tangkap, area penangkapan ikan serta jalur distribusi hasil penangkapan ikan secara ilegal mewarnai dinamika kegiatan illegal fishing di wilayah perbatasan Indonesia-Filipina. Nelayan lokal dihadapkan pada kondisi serba sulit karena harus hidup dengan berbagai kekurangan di wilayah perbatasan dan disisi lain harus bersaing dengan para pencuri ikan dari negara lain dengan alat tangkap yang jauh lebih besar. Konstruksi sosial 
setiap aktor didalam memaknai konsep illegal fishing menjadikan fenomena pencurian ikan di wilayah perbatasan selalu berkembang dengan berbagai dinamikanya.

Berdasarkan permasalahan yang dijelaskan diatas maka pertanyaan utama penelitian ini adalah sebagai berikut:

1. Bagaimana ragam jejaring illegal fishing yang berlangsung di wilayah perbatasan Indonesia-Filipina?

2. Bagaimana pola brokerage yang terjadi di dalam setiap ragam jejaring illegal fishing sehingga mampu bertahan dan terhindar dari jerat hukum?

\subsection{Maksud dan Tujuan}

Secara umum penelitian ini bertujuan mengetahui kiat yang dikembangkan oleh para pelaku illegal fishing agar kegiatannya tetap berlanjut. Setiap aktor yang terlibat dalam kegitan illegal fishing memiliki nilai-nilai, norma dan pengetahuan yang berbeda satu dengan yang lainnya. Setiap aktor yang terlibat mengembangkan jejaring yang menguntungkan dan memberi manfaat dalam kegiatan illegal fishing. Secara khusus tujuan penelitian ini adalah sebagai berikut:

1. Mengetahui ragam jejaring illegal fishing dan lembaga-lembaga sosial yang dipergunakan untuk membangun, memelihara dan mengembangkan illegal fishing.

2. Mengetahui pola brokerage dan strategi yang digunakan untuk bertahan dan terhindar dari jerat hukum.

\section{Kajian Pustaka dan Kerangka Pemikiran}

Kajian tentang illegal fishing telah banyak dikaji berbagai kalangan akademisi, dari sudut pandang ilmu hukum, ilmu ekonomi sampai ilmu hubungan internasional, yang tentu memiliki perpspektif dan ciri khas masing-masing. Dalam ranah ilmu sosiologi meneliti illegal fishing diperbatasan menjadi sangat menarik karena melibatkan banyak aktor dari ragam jejaring yang saling terkait dan sarat akan kepentingan diantara aktor-aktor tersebut. Penelitian ini tidak sekadar memotret fenomena illegal fishing yang masif terjadi di wilayah perbatasan, namun juga berusaha memetakan jaringan yang terlibat didalamnya serta berbagai bentuk respon dan adaptasi yang dilakukan oleh masing-masing aktor yang terlibat illegal fishing. Upaya untuk mencapai tujuan ini digambarkan dalam kerangka konseptual (Gambar 1.2). Kerangka konseptual penelitian ini akan dijelaskan secara runtut mulai dari entry point penelitian hingga outcome penelitian.

Entry point penelitian ini dapat dijelaskan dengan memahami konsep illegal fishing sebagai sebuah kejahatan luar biasa dan terorganisasi (Nikijuluw 2008, 25). Kejahatan (crime) dan pelanggaran (violation) merupakan tindakan yang secara nyata melawan hukum. Dalam konteks perikanan, kejahatan dan pelanggaran berarti segala sesuatu tindakan bertentangan dengan hukum positif yang menjadi payung hukum serta rujukan bagi seluruh kegiatan perikanan. Rujukan tersebut adalah Undang-Undang nomor 45 tahun 2009 tentang perubahan atas Undang-Undang nomor 31 tahun 2004 tentang perikanan. Regulasi ini mengatur secara komprehensif terkait pokok-pokok pembangunan perikanan yang berawal dari pengelolaan sumber daya perikanan, pemanfaatan, pengawasan, pengolahannya hingga pemasaran produk turunannya. 
Gambar 1.1

Kerangka Pemikiran

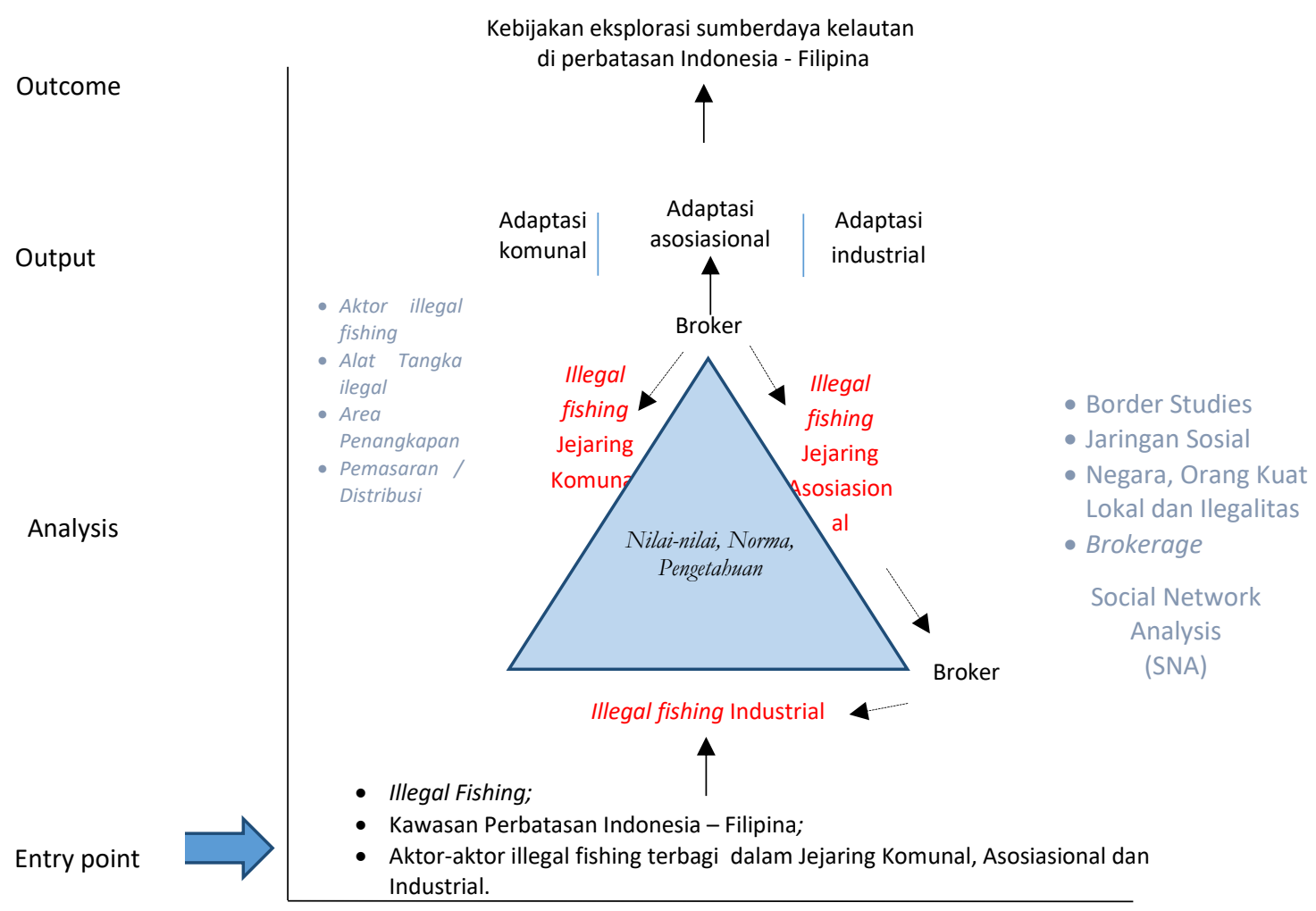

Undang-Undang nomor 45 tahun 2009 ini memberikan arah yang komprehensif terkait program pembangunan masyarakat perikanan, terutama yang berkaitan dengan pemberdayaan nelayan serta pengembangan usaha perikanan. Regulasi ini juga memuat ketentuan terkait berbagai bentuk perbuatan atau peristiwa pidana yang berkaitan dengan perikanan, perbuatan atau peristiwa pidana perikanan ini dikelompokkan menjadi dua kategori yaitu kejahatan perikanan dan pelanggaran perikanan. Kejahatan dan pelanggaran perikanan sekilas terlihat serupa, namun ada perbedaan yang signifikan antara crime dan violation. Kejahatan atau crime terjadi dikarenakan adanya pelanggaran atas hukum atau peraturan yang berlaku. Kejahatan dapat dikategorikan sebagai tindak pidana berat, lebih berat dari sekadar pelanggaran. Oleh karena itu pelanggaran merupakaan bentuk pidana yang masuk kategori ringan, lebih ringan dari kejahatan (Nikijuluw 2008, 30).

Simorangkir (dalam Nikijuluw 2008, 30) mencoba memberikan pemahaman terkait konsep kejahatan; pertama, kejahatan adalah perbuatan yang sangat anti-sosial yang oleh negara ditentang dengan sadar dengan penjatuhan hukuman. Kedua, kejahatan adalah juga perbuatan melanggar norma hukum yang ditafsirkan atau patut ditafsirkan sebagai perbuatan yang merugikan dan menjengkelkan sehingga tidak boleh dibiarkan. Ketiga, merupakan suatu tindakan anti-sosial yang menimbulkan kerugian, ketidakpatutan dalam masyarakat sehingga terjadi kegelisahan dalam masyarakat. Untuk menenteramkan masyarakat, negara harus menjatuhkan sanksi pidana kepada penjahat. Secara garis besar tindakan kejahatan maupun pelanggaran dapat dikaitkan dengan berat atau ringannya pidana. Sifat ancaman pidana bagi kejahatan tentunya lebih berat daripada pelanggaran. Bentuk kejahatan dalam konteks perikanan dapat dimaknai sebagai bentuk tindakan yang dapat mengakibatkan keparahan sosial (social injuries). 
Maraknya illegal fising di perbatasan Indonesia-Filipina terjadi karena eksistensi wilayah tersebut kaya akan sumber daya kelautan namun belum diekplorasi secara optimal, ditambah dengan minimnya prasarana dan sarana dasar seperti sarana sosial, transportasi dan sarana keamanan. Tidak mengherankan jika masyarakat yang tinggal disekitar perbatasan jauh dari sejahtera. Maraknya illegal fishing di wilayah perbatasan tidak bisa dilepaskan dari kondisi geografis yang sangat luas dan sulit dijangkau oleh keterbatasan sarana dan prasarana aparat. Berbagai modus illegal fishing dilakukan baik oleh nelayan setempat maupun nelayan asing agar tetap dapat melakukan kegiatan penangkapan ikan secara tidak sah. Illegal fishing yang terjadi di perairan perbatasan ini terjadi dari skala kecil sampai skala yang terorganisir lintas negara (transnational). Nelayan yang tinggal di pulau-pulau terluar dihadapkan pada kondisi geografis yang sulit dijangkau dari ibu kota kabupaten, disparitas harga komoditas hasil laut antara dalam negeri dan luar negeri menjadi salah satu faktor mengapa nelayan lokal lebih gemar melakukan penjualan ikan di tengah laut kepada kapal berbendera asing (transshipment).

Illegal fishing merupakan kegiatan transaksi jual beli komoditas hasil laut lintas negara melalui jalur-jalur tidak normal dengan tujuan mendapatkan profit atau keuntungan yang lebih besar, kegiatan ekonomi ilegal ini akan menjadi faktor yang berpengaruh terhadap persoalan keamanan perbatasan karena banyak kepentingan ikut bermain didalamnya, dalam konteks penelitian ini maka pihak-pihak yang bermain dari pihak Indonesia maupun pihak Filipina. Dinamika aktor yang terjalin didalam kegiatan illegal fishing akan membentuk pola jaringan yang kompleks dan saling terkait.

Kegiatan illegal fishing di wilayah perbatasan Indonesia-Filipina ini dilakukan baik oleh kapal ikan berbendera Indonesia sendiri maupun kapal ikan berbendera asing. Berbagai modus dilakukan didalam kegiatan illegal fishing, aktor-aktor yang terlibat juga dapat diklasifikasikan dari kapasitas illegal fishing itu sendiri dan juga jejaring yang dikembangkan didalam kegiatan illegal fishing. Ukuran perahu, tingkat teknologi, modal, biaya operasional menentukan lokasi kelas sosial nelayan. Kelas sosial nelayan di Kabupaten Kepulauan Talaud berkaitan erat dengan jenis atau tipe teknologi penangkapan. Nelayan dengan menggunakan jenis alat tertentu berada pada kelas tertentu pula.

Jejaring yang dikembangkan didalam illegal fishing ini dikelompokkan menjadi 3 bagian besar. Pertama, "jejaring komunal", aktor utama dari kelompok ini adalah nelayan kecil atau dalam kategori (Clement 1986, 219) disebut small-scale (petty bourgeoisie). Nelayan kecil yang secara nyata melakukan kegiatan penangkapan ikan dengan melanggar regulasi namun masih dalam skala kecil dan relatif bersifat subsistem. Motif pelanggaran yang dilakukan karena keterbatasan pengetahuan serta kuatnya ikatan kekerabatan dengan nelayan Filipina. Ketiadaan pilihan bagi masyarakat (nelayan) perbatasan didalam pemenuhan kebutuhan hidup, menjadikan praktek ilegalitas menjadi tidak terhindarkan. Pada titik inilah, berbagai bentuk kegiatan ilegal di perbatasan akan menciptakan kesejahteraan bagi masyarakatnya atau "smuggling and welfare" (Lovely and Nelson 1995, 26-45).

Kedua, jejaring yang terbangun dengan melibatkan pihak-pihak terkait pembuat kebijakan, dengan demikian kegiatan illegal fishing mendapat support dari pihak-pihak yang berwenang. Kegiatan illegal fishing dalam kategori ini menggunakan alat tangkap yang relatif lebih modern, ragam jejaring ini kemudian disebut dengan "jejaring asosiasional". kategori kelompok ini dengan sebutan intermediate-scale (small capitalist) dengan jumlah nelayan berkisar 3-9 orang (Clement 1986, 219).

Ketiga, adanya bentuk kerja sama yang lebih luas cakupannya, dalam konteks ini illegal fishing yang secara nyata dilakukan dengan jalan mensiasati berbagai bentuk kerja sama antar negara yang terlibat dalam kesepakatan penangkapan dan pengolahan hasil perikanan. Pihak yang terlibat dalam jejaring ini adalah pengusaha besar, pejabat berwenang dan aparat keamanan, jejaring ini kemudian disebut dengan "jejaring industrial". 
Teori penting untuk dapat memahami jejaring illegal fishing yang berkembang di wilayah perbatasan Indonesia-Filipina adalah jaringan sosial. Analisis jaringan sosial berdasar dari suatu pemikiran bahwa tindakan ekonomi disituasikan secara sosial dan mengakar kedalam jaringan itu sendiri. Jaringan sosial merupakan rangkaian hubungan relasional atau inter relationship antar elemen dalam suatu sistem (Granovetter 1985, 12). Studi tentang jaringan sosial (social network), marak dilakukan oleh sosiolog dan antropolog pada dekade 1970-an, umumnya dikaitkan dengan bagaimana pribadi-pribadi berhubungan antara satu sama lain dan bagaimana ikatan afiliasi melayani baik sebagai pelicin dalam memperoleh sesuatu yang dikerjakan, sebagai jembatan untuk memudahkan hubungan antara satu pihak dengan pihak lainnya, maupun sebagai perekat yang memberikan tatanan dan makna pada kehidupan sosial (Powell dan Doerr 2003, 1-5).

Jaringan sosial melihat hubungan antar individu yang memiliki makna subjektif yang berhubungan atau dikaitkan dengan sesuatu simpul dan ikatan. Simpul dilihat melalui aktor individu didalam jaringan, sedangkan ikatan merupakan hubungan diantara para aktor tersebut. Dalam kenyataan, dimungkinkan terdapat banyak jenis ikatan dan simpul. Pada tingkatan struktur, jaringan sosial dapat dipahami sebagai pola atau struktur hubungan sosial yang meningkatkan dan/atau menghambat perilaku orang untuk terlibat dalam bermacam arena dari kehidupan sosial pada tataran struktur sosial. Oleh karena itu tingkatan ini memberikan suatu dasar untuk memahami bagaimana perilaku individu dipengaruhi oleh struktur sosial (Damsar 2011, 157).

Guna menginterpretasikan tindakan sosial dari aktor yang terlibat dalam jaringan sosial, (Burt 1982, 20) menggunakan pendekatan kultural dalam jaringan sosial. Pendekatan ini berasumsi bahwa keterlibatan aktor yang ada dalam suatu jaringan melibatkan banyak orang. Sifat hubungan yang ada pada individu mungkin terdapat pada aktor lain seperti kepercayaan, persepsi dan sikap yang dilakukan terdapat pada aktor lain. Analisis kultural dalam jaringan sosial terfokus pada sebagian dari keseluruhan jaringan disebut dengan reticulum, yaitu terbatas pada analisis hubungan-hubungan relasional antar individu-individu yang langsung berhubungan dengan aktor ekonomi (ego) tertentu.

Jaringan sosial merupakan konsep analitik tidak hanya dilihat dari rangkaian hubungan relasional saja, melainkan juga dilihat bagaimana karakteristik sosial dari hubungan-hubungan relasional yang ada dapat digunakan untuk menginterpretasikan tindakan sosial dari orangorang yang terlibat didalamnya (Mitchell 1969, 10). Penelitian ini menggunakan karakteristik jaringan sosial yang ditawarkan (Mitchell 1969, 20-29), yaitu (1) content, yaitu atribut nilai, norma dan tujuan yang disepakati bersama oleh antar aktor. (2) Directedness, yaitu orientasi hubungan antara seorang aktor dengan aktor lainnya: resiprotas (timbal-balik) atau asimetris (searah). (3) Durability, yaitu seorang aktor menyadari hak dan kewajibannya untuk mengidentifikasi aktor lain. (4) Intensitas, yaitu kekuatan yang mengikat antara seorang aktor dengan aktor lainnya. (5) Frekuensi, yaitu keteraturan kontak antar seorang aktor dengan aktor lainnya.

Dari paparan diatas, maka teori jaringan sosial dapat digunakan sebagai pisau analisis didalam melihat fenomena illegal fishing di perbatasan. Illegal fishing di perbatasan harus diakui sebagai sebuah fenomena yang melibatkan banyak aktor. Masifnya illegal fishing di perbatasan menandakan lemahnya regulasi formal yang diterapkan oleh pemerintah. Masyarakat perbatasan mencoba mensiasati berbagai keterbatasan dengan praktek illegal fishing. Dengan praktek illegal fishing nelayan dapat memenuhi kebutuhan hidup sehari-hari, dalam konteks inilah jaringan sosial sebagai investasi yang dapat dimanfaatkan dalam mencapai hasil yang diharapkan. Namun dalam skala besar illegal fishing tidak semata-mata hanya untuk pemenuhan kebutuhan sehari-hari (subsisten), namun motif mendapatkan keuntungan secara ekonomi tentunya menjadi prioritas didalam menjalankan praktek illegal fishing. 
Banyak kapal-kapal Filipina yang menangkap ikan secara ilegal di wilayah perairan Kabupaten Kepulauan Talaud hingga masuk jauh ke perairan pedalaman, bahkan sangat dekat dengan pantai. Kapal-kapal Filipina ini dikenal dengan sebutan pump boat, terbuat dari kayu lapis berkualitas tinggi dengan daya jelajah mesin yang sangat tinggi. Nelayan Filipina menggunakan berbagai cara untuk mengelabui aparat pengawas di perbatasan. Banyak kapalkapal Filipina yang dicat dengan warna mencolok dan dengan nama lambang khas Indonesia, agar dianggap sebagai kapal patroli. Banyak nelayan Filipina tinggal diberbagai wilayah kecamatan di Kabupaten Kepulauan Talaud, mereka hidup dan cenderung menyatu dengan masyarakat perbatasan. Hubungan yang terjalin antara nelayan Filipina dan masyarakat perbatasan sulit untuk dipisahkan. Nelayan Filipina dengan bantuan aparat lokal bahkan dapat memiliki indentitas kependudukan, sehingga posisi mereka menjadi ambigu, disatu sisi mereka adalah warga Filipina namun disatu sisi mereka tinggal, kawin-mawin dan memiliki indentitas Indonesia.

Jarak yang begitu jauh dengan ibu kota provinsi, menjadikan kawasan perbatasan khususnya Talaud sangat subur kegiatan illegal fishing, ditambah kelangkaan sarana dan prasarana serta jumlah aparat pengawas membuat praktek illegal fishing terkesan sebagai hal yang lumrah. Jika dilakukan pengawasan atau patroli tidak pernah dilaporkan terdapat kegiatan pencurian ikan, minimal hanya kapal-kapal kecil yang ditemukan. Sebagai sebuah jaringan, kegiatan illgal fishing justru melibatkan aparat pengawas itu sendiri, sehingga jika dilakukan patroli atau pengawasan maka pencuri ikan itu telah melarikan diri karena telah mengetahui terlebih dahulu.

Kuatnya ikatan jejaring illegal fishing yang terjadi di perbatasan Indonesia-Filipina tentunya tidak dapat dilepaskan dari peran broker/perantara yang ada pada setiap bentuk jejaring. Dalam jejaring komunal, nelayan perbatasan memiliki berbagai kendala di dalam memasarkan hasil tangkapan, oleh karenanya ada pihak-pihak yang membantu membuka akses menjual hasil tangkapan ke Filipina. Dalam jejaring asosiasional dan jejaring industrial broker memiliki peran yang sangat penting, mengamankan praktek pencurian ikan agar aman dan terus berjalan. Broker dalam jejaring asosiasional dan industrial merupakan agen-agen perkapalan yang menghubungkan para pengusaha besar di daerah dengan para pejabat di tingkat pusat dalam hal pengurusan perizinan. Dikarenakan kewenangan yang berjenjang, aparat pemerintah di tingkat Provinsi atau Kabupaten/Kota juga berperan sebagai broker. Mereka menghubungkan kepentingan para pengusaha di daerah dengan pembuat kebijakan di tingkat pusat.

Broker memainkan peranan penting di dalam memfasilitasi kegiatan illegal fishing. Informasi pergerakan barang dan jasa dikuasai oleh broker, tanpa broker maka kegiatan illegal fishing di perbatasan tidak akan menjadi masalah serius. Broker dalam jejaring illegal fishing mampu menciptakan keuntungan ekonomi yang cukup besar, meskipun bagi negara merupakan sebuah kerugian. Broker dalam illegal fishing sebenarnya tidak secara langsung ikut dalam proses penangkapan ikan, namun broker mampu memberikan akses kepada pihak-pihak yang ingin membeli dan menjual ikan secara ilegal.

Secara teoritis, broker dapat dikelompokkkan dalam lima tipologi (Gould \& Fernandez 1989). Tipologi broker ini didasarkan pada arah informasi, aliran sumber daya di dalam jaringan dan posisi aktor didalam kelompok atau kelas sosial. Liaison, broker yang menghubungkan dua kelompok yang berbeda, dan ia bukanlah bagian dari kelompok yang dihubungkannya. Intinerant, broker dalam jejaring ini menghubungkan dua aktor dalam satu kelompok yang sebelumnya tidak saling berhubungan. Coordinator, broker menghubungkan dua pihak yang sebelumnya tidak saling berhubungan, broker dan kedua pihak merupakan bagian dari satu kelompok. Gatekeeper, broker yang menghubungkan satu aktor dengan aktor lainnya yang tidak saling behubungan sebelumnya dan arah tujuan informasinya adalah aktor yang merupakan bagian dari kelompok si broker. Representative, tipologi broker yang serupa dengan 
gatekeeper, peran broker menghubungkan aktor yang satu kelompok dengannya terhadap aktor di luar kelompoknya, yang sebelumnya tidak pernah berhubungan.

Broker merupakan perantara dalam sebuah sistem sosial, ekonomi atau politik yang memfasilitasi berbagai bentuk perdagangan atau transmisi sumber daya yang berharga. Broker memiliki peran menjembatani kesenjangan yang ada dalam sebuah struktur sosial, dan broker membantu mendistribusikan barang, informasi, peluang dan pengetahuan yang tidak dimiliki oleh pihak lain. Singkatnya, broker adalah perantara yang menghubungkan dua aktor atau lebih yang sebelumnya tidak terkait satu dengan yang lainnya. Kajian tentang brokerage akan memperdalam analisis ragam jejaring illegal fishing, kemampuan broker di dalam menghubungkan berbagai kepentingan menjadikan ikatan diantara pelaku illegal fishing semakin kuat (Boissevain 1969, 379-386).

Otoritas dan kekuasaan yang dimiliki oleh pejabat negara, sering kali disalahgunakan untuk kepentingan pribadi maupun kelompoknya. Kewenangan yang dimiliki oleh pejabat negara maupun aparatur negara lainnya dapat memposisikan mereka sebagai patron yang selalu menggunakan berbagai cara untuk menguasai sumber daya. Dalam hal penguasaan sumber daya ini, patron dapat bertindak sebagai broker untuk menghubungkan para pihak yang berkepentingan untuk mendapatkan keuntungan. Broker berusaha untuk menjembatani kesenjangan komunikasi dalam kelompok, struktur bahkan budaya. Broker memainkan peran sebagai manipulator profesional untuk membawa pesan, dengan demikian broker menempati posisi strategis dalam sebuah jaringan sosial (Boissevain 1969, 380).

\section{Objek dan Metode Penelitian}

Analisis data dalam penelitian ini menggunakan pendekatan Social Network Analysis (SNA), yang merupakan analisis metodis dari jaringan sosial. Analisis jaringan sosial memandang hubungan sosial yang terdiri dari node (mewakili aktor individual dalam jaringan) dan koneksi atau link (yang mewakili hubungan antara individu). Adapun langkah-langkah analisis jaringan sosial adalah sebagai berikut: (1) mengidentifikasi klik-klik yang ada dalam suatu sistem, (2) mengidentifikasi peran jaringan melalui network articulation dalam jaringan seperti peran sebagai pusat (star), perantara (liason), anggota (member), (3) menginterpretasikan karakteristik hubungan relasional antar aktor secara sosial budaya (Wijaya 2006, 32).

Lokasi penelitian ini dilakukan berawal di wilayah perairan Kabupaten Kepulauan Talaud, kemudian Kota Bitung sebagai sentra utama perikanan di Sulawesi Utara dan Jakarta sebagai Ibu Kota Negara tempat kedudukan Kantor Kementerian Kelautan dan Perikanan yang memiliki kewenangan terkait masalah illegal fishing, serta beberapa kantor Kementerian/Lembaga lain yang berkaitan dengan fenomena illegal fishing. Secara spesifik lokasi penelitian dilakukan di pulau-pulau terluar di Kabupaten Kepulauan Talaud, seperti Pulau Miangas, Pulau Nanusa dan Pulau Karekelang. 


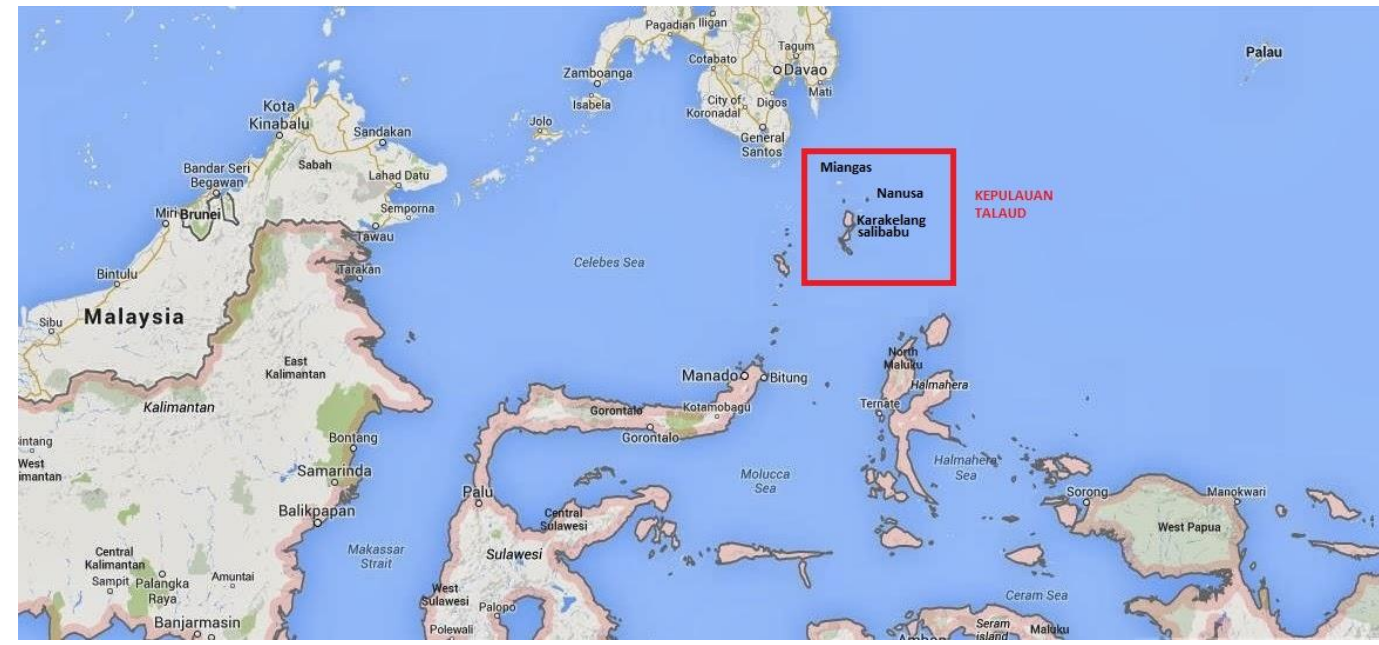

Gambar 1.2 Lokasi Penelitian

Data terkait interaksi antar aktor yang terkait di dalam illegal fishing diperoleh melalui wawancara mendalam, dengan panduan wawancara yang telah dipersiapkan sebelumnya. Pengumpulan data primer ini berkaitan dengan gagasan, pemikiran, pengetahuan, tindakan dan interaksi masyarakat perbatasan di dalam kegiatan illegal fishing dikumpulkan dari informan kunci yang memang secara nyata aktif terlibat. Penetapan informan kunci berdasarkan informasi dari narasumber dengan cara "snowball”. Subjek yang diwawancarai antara lain:

1) Masyarakat nelayan di sekitar wilayah perbatasan Indonesia - Filipina (P. Miangas, P. Karekelang, P. Nanusa)

2) Bupati/Wakil Bupati Kabupaten Kepulauan Talaud

3) Unsur Pengusaha Perikanan Talaud

4) Unsur Dinas Kelautan dan Perikanan Kabupaten Kepulauan Talaud

5) Unsur Polres Kabupaten Kepulauan Talaud

6) Unsur Kementerian Kelautan dan Perikanan

7) Unsur Kementerian Perhubungan

8) Unsur LSM/NGO

9) Unsur aparat keamanan

\section{Hasil dan Pembahasan}

Penelitian ini menyumbangkan kategorisasi ragam jejaring illegal fishing ke dalam tiga kelompok besar . Pertama, jejaring komunal yaitu ragam jejaring illegal fishing yang dilakukan oleh nelayan kecil, menggunakan alat tangkap sederhana dan relatif bersifat subsistem. Kedua, jejaring asosiasional yaitu bentuk jejaring yang terbangun dengan melibatkan pihak-pihak terkait/berwenang dalam konteks regional dengan alat tangkap yang relatif lebih maju, dan Ketiga, jejaring industrial yaitu jejaring yang merupakan representasi bentuk jaringan kerja sama yang lebih luas cakupannya dengan melibatkan aktor seperti nelayan skala industri, pengusaha besar perikanan dalam dan luar negeri serta didukung oleh aparat baik di tingkat pusat maupun daerah.

Dalam jejaring komunal, masyarakat perbatasan dalam hal ini nelayan kecil yang mengeksploitasi hasil laut merasa tidak melakukan penangkapan ikan/hasil laut secara ilegal. Dengan demikian tentu saja terdapat perbedaan pemahaman tentang eksplorasi pemanfaatan hasil laut di kawasan perbatasan Indonesia-Filipina antara negara/pemerintah dengan masyarakat setempat. Dalam perspektif nelayan kecil, apa yang mereka lakukan adalah sekadar menangkap ikan untuk bertahan hidup dan mereka tidak mengetahui jika apa yang mereka 
lakukan adalah ilegal. Jaringan sosial yang dipergunakan dalam kategori komunal ini adalah jaringan tradisional seperti jaringan keluarga, jaringan etnis dan jaringan agama. Keterlibatan nelayan perbatasan dalam jejaring illegal fishing ini lebih dikarenakan adanya perbedaan konstruksi pengetahuan masyarakat nelayan tentang konsep ilegalitas. Bagi nelayan perbatasan praktik kegiatan ilegal seperti menangkap ikan diluar batas negara, menangkap komoditas hasil laut yang dilarang dalam regulasi, menangkap dengan alat tangkap yang dilarang dalam regulasi, menjual/mendistribusikan komoditas hasil laut tidak sesuai dengan regulasi telah mereka lakukan jauh sebelum Indonesia merdeka. Hal ini mengindikasikan bahwa jauh sebelum negara ini diproklamirkan kegiatan penangkapan ikan telah mereka lakukan, dan kegiatan tersebut kemudian dikategorikan ilegal justru dikarenakan lahirnya negara.

Praktik illegal fishing yang dilakukan oleh nelayan perbatasan dilakukan karena ketiadaan pilihan, pemerintah melarang berbagai bentuk praktik pengelolaan perikanan namun pemerintah juga tidak memberikan jalan keluar untuk meningkatkan taraf hidup nelayan perbatasan. Dalam konstruksi pemerintah pengelolaan perikanan yang dilakukan oleh nelayan perbatasan dengan menjual hasil tangkapan ke Filipina merupakan wujud nyata dari illegal fishing, namun sekali lagi itu semua dilakukan nelayan karena ketiadaan pilihan. Dalam perspektif nelayan perbatasan jika tidak menjual hasil tangkapan ke Filipina maka mereka akan mati, dan pada titik inilah kegiatan yang oleh negara dipandang ilegal justru mensejahterakan masyarakat perbatasan.

Dalam lingkup jejaring asosiasional dan jerjaring industrial, motif praktik pencurian ikan tidak lagi sekadar untuk bertahan hidup namun sudah berorientasi pada motif mencari keuntungan secara ekonomi. Keterlibatan oknum aparat, pengusaha perikanan dan nelayan skala menengah terjalin dengan membentuk sebuah jaringan yang sistematis. Berbagai cara dilakukan untuk mensiasati berbagai regulasi yang mengatur tentang perikanan. Dalam jejaring asosiasional, keterlibatan aparatur daerah sangat kentara, keterlibatan nelayan lokal dalam lingkup ini hanya sekadar tameng/kamuflase semata. Dalam lingkup jejaring industrial, illegal fishing terjadi sejak dalam proses pengurusan izin di tingkat pusat. Proses pengurusan perijinan sarat dengan praktik suap dan berkas pendukung kebanyakan tidak sesuai dengan kondisi di lapangan. Jejaring illegal fishing asosiasional dan industrial ini dapat dikategorikan sebagai sebuah bentuk kejahatan teroganisasi (organized crime), karena praktik pencurian ikan di perbatasan dilakukan secara terorganisasi; pemasok, pengepul/penampung, pengemasan hingga distribusi hasil tangkapan terkendali secara terstruktur.

Konfigurasi jaringan yang terbentuk pada setiap level praktik illegal fishing tidak dapat dilepaskan dari peranan broker/perantara. Dalam analisis jaringan sosial, broker memiliki peran sentral di dalam menghubungkan antar aktor. Illegal fishing dalam jejaring komunal, broker menghubungkan nelayan kecil dengan nelayan Filipina untuk mempermudah distribusi hasil tangkapan. Peranan broker di dalam jejaring komunal dimiliki oleh tokoh adat manpun tokoh agama. Sementara, broker di dalam jejaring asosiasional dan industrial adalah agen perikanan dan aparat itu sendiri. Dalam jejaring asosiasional, agen-agen perikanan akan menghubungkan pengusaha perikanan dengan aparat untuk memperlancar usaha perikanan. Dalam jejaring industrial peran broker justru dimiliki oleh aparat-aparat daerah yang memiliki akses ke intansi pusat dalam hal ini Kementerian Kelautan dan Perikanan dan Kementerian Perhubungan. Aparat daerah menjadi penghubung bagi pengusaha perikanan daerah ketika hendak mengurus perizinan di tingkat pusat. Agen-agen pengurus perizinan perikanan di tingkat pusat mayoritas justru dimiliki oleh aparat.

Peran broker yang dimainkan oleh oknum aparat terjadi juga di tingkat pengadilan perikanan. Pengadilan perikanan yang seharusnya menjadi ujung tombak di dalam penegakan hukum justru terciderai oleh ulah oknum yang selalu ada dalam setiap instansi peradilan perikanan. Dari hasil penelitian, panitera merupakan broker yang menjadi pintu masuk bagi pengusaha perikanan yang berperkara di pengadilan perikanan. Banyaknya kasus perikanan 
yang masuk ke peradilan, hanya sebagian kecil yang dihukum berat, sebagian hanya dihukum denda bahkan tidak sedikit yang dibebaskan. Tidak heran kemudian, jika berbagai upaya memerangi illegal fishing seolah-olah menemui jalan buntu. Keterlibatan aparat sebagai broker merupakan titik lemah penegakan regulasi perikanan, terlebih di wilayah perbatasan.

Broker memegang peranan yang sangat krusial di dalam jejaring illegal fishing. Broker berperan dari hulu hingga hilir praktik perikanan ilegal, dari berperan sebagai perantara proses perizinan hingga mendistribusikan hasil tangkapan. Peran broker yang dimainkan oleh aparat tentunya akan sangat sulit terdeteksi. Aparat sebagai representasi dari negara adalah pihak yang secara normatif hendaknya mematuhi segala bentuk regulasi formal, bahkan patut untuk dijadikan panutan bagi warga masyarakat. Pengetahuan aparat terkait celah-celah regulasi ditambah dengan motif pencarian keuntungan pribadi menjadikan banyak oknum aparat yang terlibat dalam illegal fishing dengan berperan sebagai broker. Kemampuan aparat di dalam mensiasati berbagai celah perizinan ternyata membentuk tipologi baru teori brokerage. Uncertain Gatekeeper merupakan model pengembangan teori brokerage (Gould dan Fernandes 1989), di mana model ini terbentuk karena adanya proses adaptasi aparat yang menjadi penghubung/perantara antara pelaku bisnis perikanan dengan pejabat pembuat perzinan.

Penelitian dengan tema illegal fishing di Talaud ini menyimpulkan bahwa aktor yang dominan dalam kegiatan pencurian ikan di wilayah pengelolaan perikanan Republik Indonesia adalah negara dan swasta besar. Dominannya negara dan swasta besar ini justru menyebabkan apa yang oleh Bryant dan Bailey sebagai tragedy of enclosure, yaitu sebuah tragedi akibat dominasi negara dan swasta yang menyebabkan akses masyarakat pada pemanfaatan dan pengelolaan sumber daya kelautan semakin dibatasi namun dengan dalih konservasi dan penegakan hukum, di balik itu semua negara melalui aparatnya justru terlibat dalam kegiatan ilegal.

Analisa jaringan sosial dapat dilakukan baik dalam tataran individu maupun dalam tataran struktur. Dalam tataran individu, jaringan sosial dilihat melalui rangkaian hubungan yang khas di antara sejumlah individu, dengan ciri-ciri dari hubungan tersebut digunakan sebagai dasar untuk menginterpretasikan tingkah laku sosial dari masing-masing individu yang ada dalam komunitas tersebut. Kajian Granovetter (Kadusin 2004, 5) menyatakan bahwa jaringan sosial merupakan suatu rangkaian hubungan yang teratur dan terpola, dalam hal ini terdiri minimal dari dua objek pelaku yang masing-masing memiliki identitas dan dihubungkan melalui hubungan sosial yang ada. Melalui hubungan sosial, individu tersebut dapat dikelompokkan sebagai sebuah kesatuan sosial. Studi jaringan sosial dalam kegiatan illegal fishing dalam tataran analisis melihat hubungan antar individu yang memiliki makna subjektif yang berhubungan atau dikorelasikan dan membentuk suatu simpul atau ikatan. Ikatan merupakan manifestasi hubungan antar aktor sementara simpul dilihat melalui aktor individu dalam jaringan. Dalam tataran realitas terdapat banyak jenis ikatan antar simpul.

Dalam penelitian ini, pembedaan/klasifikasi skala illegal fishing juga menggunakan rujukan (Satria 2015, 5). Pembedaan skala illegal fishing ini sejalan dengan keragaman status aktor (nelayan), yaitu: peasant-fisher, post-peasant fisher, comercial fisher dan industrial fisher. Pembedaan keragaman muncul atas keterbatasan beberapa kajian yang hanya mengklasifikasikan aktor (nelayan) ke dalam dua kelompok: large scale fisherman dan small scale fisherman.

Dalam analis jaringan, ditawarkan tiga tingkatan yaitu: jaringan mikro, jaringan meso dan jaringan makro. Tingkatan jaringan ini linier dengan pembedaan skala dalam kegiatan illegal fishing. Illegal fishing dalam jejaring komunal dalam tataran teori masuk dalam tingkatan jaringan mikro, aktor utama jaringan ini adalah masyarakat (nelayan kecil). Dalam jaringan (sosial) mikro terwujud dalam bentuk interaksi sosial sehari-hari. Apa yang dilakukan oleh nelayan (peasant-fisher) di perbatasan Indonesia-Filipina, khususnya di sekitaran Pulau Miangas dan Nanusa adalah sebuah bentuk pilihan rasional (rational choice). 
Konsep "illegal" yang dibentuk oleh negara tampaknya tidak begitu berarti bagi nelayan perbatasan. Perbedaan pengetahuan antara negara dengan masyarakat perbatasan terkait konsep illegal fishing pada gilirannya akan selalu menempatkan masyarakat perbatasan sebagai "pelanggar hukum". Bagi nelayan perbatasan, kegiatan mencari ikan tidak lebih dari sekadar mempertahankan hidup. Tinggal di perbatasan bukanlah suatu pilihan. Jauh sebelum negara hadir, kegiatan lintas batas negara adalah hal yang biasa mereka lakukan. Kegiatan pemenuhan kebutuhan hidup diperoleh dengan transaksi lintas batas negara, sampai kemudian negara hadir dan menyatakan apa yang dilakukan masyarakat perbatasan adalah illegal.

Pola jaringan yang terbentuk dalam kegiatan illegal fishing komunal tentunya tidak dapat dilepaskan dari struktur sosial yang terbentuk dalam komunitas masyarakat nelayan. Seperti dalam analisis mainstream, struktur sosial masyarakat nelayan memiliki ciri ikatan patron-klien yang begitu kuat. Nelayan kecil (peasant-fisher) adalah klien dan patronnya adalah pemodal atau nelayan menengah (commercial fisher). Seperti telah dipaparkan dalam analisis sebelumnya, kuatnya ikatan dalam hubungan patron-klien tersebut merupakan konsekuensi logis dari bentuk penangkapan ikan yang bersifat subsisten, penuh resiko dan ketidakpastian.

Ikatan yang terajut dalam hubungan patron-klien ini pada gilirannya bersifat "mutualisme", meskipun apabila dikaji lebih kritis maka derajat keuntungan masing-masing posisi akan terlihat ketimpangan. Dalam perspektif kritis pasti patron dipandang "menang" mutlak atas klien, yaitu patron memperoleh keuntungan penuh atas klien dan cenderung bersifat eksploitatif. Analisis tersebut memang tidak sepenuhnya salah, namun dalam konteks masyarakat perbatasan yang tidak memiliki banyak pilihan dan di tengah ketidakhadiran negara maka pola patron-klien memberi dampak positif serta menjadi pemicu terjadinya mobilitas vertikal pada masyarakat nelayan perbatasan. Nelayan kecil (peasant-fisher) dapat memiliki (menggunakan) alat tangkap lebih modern seperti misalnya motor tempel, yang lebih tangguh di dalam menghadapi ketidakmenentuan cuaca. Secara riil peneliti melihat bahwa ikatan yang terbentuk antara patron klien pada masyarakat perbatasan dapat membawa nelayan kecil (Peasant-fisher) keluar dari lingkar kemiskinan absolut.

Illegal fishing dalam jejaring asosiasional (terorganisir) merupakan bentuk nyata dari konsep jaringan meso. Aktor utama dalam tingkatan meso ini adalah nelayan menengah (postpeasant fisher) dengan melibatkan aparat di tingkat lokal/daerah. Interaksi antar aktor terjadi dalam satu konteks sosial dan terbentuk kelompok tertentu. Seperti jaringan dalan tingkatan mikro, pada tingkatan meso jaringan berfungsi sebagai pelicin, sebagai jembatan dan sebagai perekat.

Fungsi pelicin dalam jaringan sosial pada tingkat meso dapat dilihat pada kemudahan aktor illegal fishing di dalam melakukan tindakan pencurian ikan. Aparat yang seharusnya menegakkan regulasi pada kenyataannya justru ikut berperan serta dalam kegiatan pencurian ikan. Fungsi jembatan (bridging) dalam tataran meso dapat jelas terlihat melalui daya hubung atau kekuatan yang dimiliki oleh aktor yang terlibat dalam kegiatan illegal fishing. Kelompok nelayan tertentu akan memiliki utusan tersendiri jika berhadapan dengan aparat, begitu juga sebaliknya aparat yang terlibat dalam kegiatan illegal fishing dalam berbagi tingkatan akan melakukan interaksi sesuai peran dan kewenangan yang dimilikinya.

Fungsi perekat dalam tataran meso jaringan sosial illegal fishing dapat dipahami melalui kemampuan kelompok-kelompok yang terlibat dalam kegiatan illegal fishing di dalam memberikan suatu tatanan dan makna pada kehidupan sosial mereka. Artinya, aktor yang tertlibat dalam praktik illegal fishing ini wajib memagari atau menjaga ruang sosialnya, sesama aktor yang masuk dalam komunitas ini direkatkan dalam sebuah organisasi yang oleh negara disebut sebagai "pencuri” ikan.

Dalam lingkup yang lebih luas, illegal fishing dalam jejaring industrial masuk dalam kategori jaringan makro. Jaringan ini merupakan ikatan yang terbentuk atas jalinan simpulsimpul dari beberapa kelompok pelaku illegal fishing dalam skala industri besar. Dengan kata 
lain, jejaring illegal fishing industrial ini terajut dari berbagai ikatan kelompok pelaku illegal fishing yang berasal dari daerah, pusat dalam dan luar negeri. Kelompok dalam konteks ini dapat dalam bentuk organisasi nelayan daerah, organisasi pengusaha pusat/daerah, institusi, bahkan negara yang termanifestasi dalam bentuk keterlibatan aparatur dalam praktik illegal fishing. Kuatnya ikatan simpul para pelaku illegal fishing dalam jejaring semi-resmi pada gilirannya mereka juga disebut dengan para mafia illegal fishing.

Melihat motif para aktor yang terlibat dalam berbagai tingkat jaringan illegal fishing, pendekatan Granovetter (1985) dapat digunakan untuk menganalisis motif apa yang melatarbelakangi para pelaku. Pelaku illeggal fishing dalam jejaring komunal adalah para nelayan kecil / peasant-fisher, tindakan mereka yang dikategorikan ilegal oleh negara adalah tindakan ekonomi kultural yang dituntun oleh aturan berupa nilai dan norma yang terinternalisasi. Dalam ranah kajian sosiologi ekonomi, tindakan ekonomi kultural ini berada dalam kubu oversocialized. Sementara pelaku illegal fishing dalam jejaring asosiasional (terorganisasi) dan industrial adalah tindakan ekonomi yang rasional dan berorientasi pada pencapaian keuntungan (profit). Dalam ranah kajian sosiologi ekonomi tindakan ekonomi yang profit oriented ini berada dalam kubu undersocialized.

Illegal fishing yang dilakukan oleh para aktor dalam jejaring asosiasional (terorganisasi) dan industrial ini merupakan bagian dari tindakan ekonomi undersocialized, melihat kepentingan individu atau kelompok adalah segalanya. Tidak ada ruang bagi pengaruh budaya, agama dan struktur sosial terhadap tindakan ekonomi. Setiap tindakan ekonomi merupakan refleksi dari satu pencapaian keuntungan pribadi/kroni- nya. Hal utama yang menjadi prioritas kelompok dalam jaringan ini adalah ratio untung-rugi (cost-benefit ratio).

Keterlibatan aparat dalam lingkaran illegal fishing dapat dimaknai sebagai sebuah bentuk dari kejahatan korporasi. Criminal corporation merupakan korporasi yang sengaja dibentuk dan dikendalikan untuk melakukan kejahatan. Kedudukan korporasi dalam criminal corporation hanyalah sebagai sarana untuk melakukan kejahatan (Mahmudah 2015, 92). Konsep white collar crime mencoba mendekonstruksi teori tentang perilaku kriminal yang secara stereotip mengatakan bahwa pelaku kejahatan adalah orang-orang yang berasal dari kelas sosial dan ekonomi rendah seperti kejahatan pencurian, perkosaan dan kejahatan kekerasan lainnya. Dengan teori white collar crime kita dapat memperoleh gambaran bahwa kejahatan merupakan fenomena yang dapat ditemukan juga dalam kelas-kelas sosial masyarakat yang lebih tinggi, yang jika ditelisik faktor motifnya tidak dapat dijelaskan secara tradisional seperti karena alasan faktor kemiskinan atau faktor patologis lain yang bersifat individual.

\section{Kesimpulan dan Rekomendasi}

Illegal fishing dan bentuk kejahatan perikanan saat ini telah menemukan konfigurasi yang bersifat transnasional dan terorganisasi. Illegal fishing sering berkaitan dengan kejahatan lain seperti perdagangan manusia, penyelundupan, narkoba, pencucian uang serta perdagangan satwa yang dilindungi. Secara intitusional pengelolaan keamanan di wilayah perbatasan terdiri dua elemen utama, yakni Tentara Nasional Indonesia (TNI) dan Kepolisian Negara Republik Indonesia (POLRI). Kedua institusi tersebut memiliki pijakan aturan yang kuat dan relevan dalam persoalan pengelolaan keamanan wilayah perbatasan, namun dalam kenyataan di lapangan pegawai dari kedua lembaga tersebut justru menjadi aktor yang dominan memberikan perlindungan (becking/beking lih. Lindsey 2006, 32) terhadap berbagai bentuk pelanggaran hukum di wilayah perbatasan.

Penelitian ini mempertegas hasil studi yang dilakukan oleh Agnew dkk. yang menyatakan adanya korelasi antara masifnya kegiatan illegal fishing dengan indeks tata kelola negara yang dikeluarkan oleh Bank Dunia. Praktik perikanan ilegal masif terjadi pada negara yang memiliki indeks tata kelola yang rendah, yang umumnya terjadi pada negara dunia ketiga. 
Keterlibatan aparat penegak hukum, birokrat/pejabat serta pengusaha dalam praktik mafia illegal fishing merupakan manifestasi dari buruknya tata kelola di Indonesia, namun penelitian ini menolak tesis (Nikijuluw 2008, xviii), yang menyatakan bahwa praktik perikanan ilegal $100 \%$ dilakukan oleh pihak asing, sebaliknya penelitian ini menyimpulkan bahwa praktik perikanan ilegal (illegal fishing) menjadi masif justru karena difasilitasi oleh negara (Satria 2015, 164).

Peranan broker/perantara dalam kegiatan illegal fishing memang tidak secara langsung terlibat dalam proses pencarian/penangkapan ikan, namun karena peran broker inilah praktik pencurian ikan seolah-olah menjadi kegiatan yang legal dan dapat terus beroperasi. Penelitian ini memperkenalkan konsep uncertain gatekeeper. Dalam tipologi broker yang ditawarkan oleh (Gould dan Fernandez, 1989) gatekeeper brokerage merupakan gambaran dari broker yang menghubungkan satu aktor dengan aktor lainnya yang tidak saling behubungan sebelumnya, dan arah tujuan informasinya adalah aktor yang merupakan bagian dari kelompok si broker. Kondisi ini berbeda dengan uncertain gatekeeper, pihak yang berperan sebagai broker adalah pejabat/aparat sendiri namun seolah-olah berperan menjadi agen. Agen dimiliki sebenarnya oleh pejabat/aparat, namun seolah-olah kepemilikannya tidak ada hubungannya dengan pejabat pembuat kebijakan. Broker dalam uncertain gatekeeper posisinya menjadi ambigu, disatu sisi terlihat sebagai pihak luar namun sebenarnya dia adalah perpanjangan tangan perjabat pembuat kebijakan.

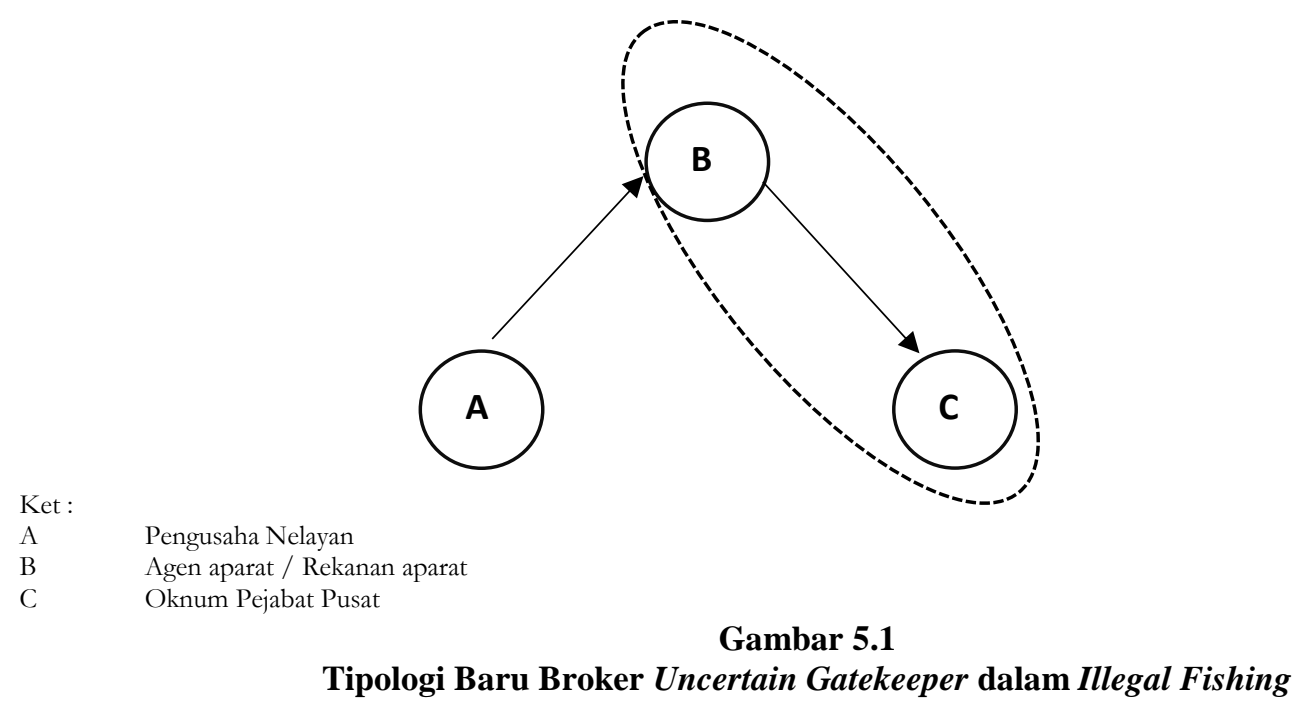

Penelitian ini merekomendasikan; Pertama, terkait fenomena illegal fishing yang terjadi dalam jejaring komunal diperlukan berbagi bentuk pengembangan perikanan rakyat. Ciri khas perikanan perbatasan adalah dominasi perikanan rakyat, artifisial, subsisten dan skala kecil. Kondisi ini tentunya mengisyaratkan bahwa kekuatan rakyat dalam jumlah besar dapat ikut serta dan terlibat dalam kegiatan ekonomi regional, meskipun ciri ini pada giliranya juga mencerminkan ketidakmampuan negara dalam mengoptimalkan sumber daya kelautan khususnya di wilayah perbatasan.

Kedua, illegal fishing yang terjadi dalam jejaring asosiasional dan industrial bermula dari praktik penyalahgunaan wewenang pemberian izin penangkapan ikan yang tidak sesuai 
prosedur. Oleh karena itu, diperlukan pembenahan sistem perizinan di tingkat pusat maupun di daerah menjadi bagian penting di dalam meminimalisir illegal fishing. Sistem on-line dalam proses perizinan yang terintegrasi pusat-daerah dan lintas instansi dapat memantau berbagai bentuk penyalahgunaan wewenang serta kontrol yang semakin mudah. 


\section{DAFTAR PUSTAKA}

\section{Buku}

Boissevain, John .1969. Patrons As Brokers. Soc Gids 16:379-386.

Bondaroff, Teale N. 2015. The Illegal Fishing And Organized Crime Nexus: Illegal Fishing As Transnational Organized Crime. The Global Initiative Against Transnational Organized Crime, Genewa - Switzerland and The Black Fish, Amsterdam - Netherlands.

Clement, William. 1986. The struggle to organize: resistance in Canada's fishery. Mcclellanf and Stewart, Toronto, Ont. 219p.

Damsar. 2011. Pengantar Sosiologi Ekonomi. Kencana. Jakarta.

Granovetter. 1985. The Economic Sociology of Firm and Enterpreneurs. dalam A. Portes (ed.) The Economic Sociology of Immigration. Russel Sage Foundation-NY.

Mahmudah, Nunung. 2015. Illegal Fishing; Pertanggungjawaban Pidana Korporasi di Wilayah Perairan Indonesia. Jakarta - Sinar Grafika.

Mitchell, Jole Cabbo. 1969. "The Concept and Use of Social Networks”, in: J.C. Mitchell (ed.) Social Network in Urban Situation. Manchester University Press.

Nikijuluw, Victor. PH. 2008. Dimensi Sosial Ekonomi Perikanan Ilegal. Pustaka Cidesindo. Jakarta.

Palma, Mary Ann and Martin Tsamenyi, 2008. Case Study on the Impact of Illegal, Unreported and Unregulated (IUU) Fishing in the Sulawesi Sea. APEC Fisheries Working Group. Singapore.

Powell, Wale Wender and Smith-Doer. 2003. "Networks and Economics Life", dalam N.J. Smelser and R. Swedberg (eds.) The Handbook of Economics Sociology.New York: Princeton University Press.

Satria, Arif. 2015. Pengantar Sosiologi Masyarakat Pesisir. Yayasan Pustaka Obor Indonesia. Jakarta.

Satria, Arif. 2015. Politik Kelautan Dan Perikanan: Catatan Perjalanan Kebijakan Era SBY hingga Jokowi. Yayasan Pustaka Obor Indonesia. Jakarta.

Wijaya, Mahendra. 2006. "Ekonomi Komersial Ganda: Perkembangan Kompleksitas Jaringan Sosial Ekonomi Perbatikan di Surakarta”. Universitas Sebelas Maret Surakarta.

\section{Jurnal}

Gould, Robert. Vande., \& Fernandez, Roy. May. 1989. Structures of mediation: A formal approach to brokerage in transaction networks. Sociological Methodology, 19, 89-126.

Lovely, Mary El and Nelson, Douglas. 1995. Smuggling and Welfare in a Ricardo - Viner Economy. Journal of Economics Studies Vol. 22.

Osterblom, Henrik, Andrew Constable and Sayaka Fukumi. 2011. Illegal Fishing and the organized crime analogy, Trends in Ecology and Evolution. Juni 2011, vol.26, No. 6 pp. 261-262.

Telesetsky, Anastasia. 2015. Laundering Fish in the Global Undercurrents: Illegal, Unreported, and Unregulated Fishing and Transnational Organized Crime. Ecology Law Quarterly Vol. 41 Issue 4. pp. 939-997.

\section{Internet}

Martini, Maira. 2013. "Illegal, Unreported, and Unregulated Fishing and Corruption." U4 Expert Answer, Transparency International, Article 392. September 5, 2013. (dalam 
http://www.u4.no/publications/illegal-unreported-and-unregulated-fishingandcorruption/downloadasset/3261, diakses pada 12 September 2017).

Putt and Anderson. 2007. "Hout Bay Fishing Company Found Guilty." (dalam http://www.iol.co.za/news/south-africa/hout-bay-fishing-company-found-guilty1.85806\#.VHvswNLF8rU, diakses pada 12 September 2017. 